\title{
PERLINDUNGAN HUKUM TERHADAP ANAK LUAR KAWIN DALAM PEMBAGIAN WARIS ADAT TORAJA
}

\author{
Olivia Irianty Logo Tadu \\ Program Magister Kenotariatan Fakultas Hukum Universitas Brawijaya \\ JI. MT. Haryono No 169; Malang; 65145; Indonesia;(0341) 553898 \\ olivialogotadu1@gmail.com
}

\begin{abstract}
The Decision of the Constitutional Court of the Republic of Indonesia Number 46 / PUU-VIII / 2010 has a positive impact on outsiders in demanding their rights to their biological father, the position of the child outside the marriage has only a civic relationship with the mother and the mother's family. Issued by the Constitutional Court Decision, the relationship of civility of children outside of marriage is not only related to mother and mother's family but with biological father and his father's family, Toraja's inheritance system has a fair system, if the outsider has no rights, demanding his right to his biological father, by deliberation but if the deliberation can not be resolved then it can be solved by the intervention of the Toraja adat chairman, if masi does not have a bright spot then the outsider can claim his rights in court, but in Adat Toaraja this community masi has a sense of kinship so that masi can be resolved, because if it has come to the village head or customary head then the family will be made into the ingredients of the local community.
\end{abstract}

Keywords:Division of Toraja's Inheritance, Legal Protection, Outer Child Marriage.

\begin{abstract}
Abstrak
Putusan Mahkamah Konstitusi Nomor 46/PUU-VIII/2010 memberikan dampak positif bagi anak luar kawin dalam menuntut hak-haknya kepada ayah biologisnya, kedudukan anak diluar perkawinanhanya memiliki hubungan dalam bidang keperdataan dengan ibu dan keluarga ibu. Dikeluarkan Putusan Mahkamah Konstitusi tersebut maka hubungan pertalian keperdataan anak diluar perkawianan tidak hanya memiliki pertalian dengan ibu dan keluarga ibunya saja namun dengan ayah biologis dan keluarga ayahnya, Sistem pewarisan di Toraja memiliki system yang adil, jika anak luar kawin tidak memiliki hak, anak tersebut dapat, menuntut haknya kepada ayah biologisnya, dengan musyawarah namun jika dengan musyawarah tidak dapat diselesaikan maka dapat diselesaikan dengan campur tangan ketua adat Toraja, jika masi belum memiliki titik terang maka anak luar kawin dapat menuntut hak-haknya di pengadilan, namun dalam Adat Toaraja ini masyarakatnya masi memiliki rasa kekeluargaan sehingga masi bisa teratasi, karena jika sudah sampai pada kepala desa atau kepala adat maka keluarga tersebut akan di jadikan bahan omongan masyarakat setempat.
\end{abstract}

Kata Kunci: Anak Luar Kawin, Pembagian Waris Toraja, Perlindungan Hukum. 
Indonesia memiliki aturan-aturan perkawinan yang sudah ada sejak dahulu, dalam aturan-aturan tersebut dipertahankan oleh masyarakat adat dan para pemuka agama. Hilman Hadikusuma (2007), yang menyatakan," Aturan tata-tertib perkawinan sudah ada sejak masyarakat sederhana yang dipertahankan anggota - anggota masyarakat dan para pemuka masyarakat adat dan atau para pemuka agama. Aturan tatatertib itu terus berkembang maju dalam masyarakat yang mempunyai kekuasaan pemerintahan di dalam suatu negara. Di Indonesia aturan tata - tertib perkawinan itu sudah ada sejak zaman kuno, sejak zaman Sriwijaya, Majapahit, sampai masa kolonial Belanda dan sampai Indonesia telah merdeka. Bahkan aturan perkawinan itu sudah tidak saja menyangkut warga negara Indonesia, tetapi juga menyangkut warga negara asing, karena bertambah luasnya pergaulan bangsa Indonesia".

Anak luar kawin secara prinsip Hukum Adat dicela, tetapi merupakan kajian yang menarik bila ternyata cela hukum adat terhadap anak luar kawin justru dapat dikesampingkan, di mana pada kenyataannya penyimpangan yang dimaksud terjadi juga dengan kepercayaan masyarakat adat akan terjadi permasalahan yang bersumber dari kentalnya kepercayaan masyarakat adat terhadap mitos yang ada, sehingga anak luar kawin dikucilkan oleh masyarakat adat (Adiarta, 2015).

Tujuan dalam suatu pernikahan adalah untuk membentuk keluarga yang bahagia, sejaterah serta untuk mempersatukan kedua keluarga dan meneruskan keturunan, perkawinan yang idel merupakan idaman bagi setiap keluarga, dimana dalam suatu keluarga tersebut lebih lengkap jika memiliki seorang anak, karena anak memiliki peran yang sangat penting sehingga menjadi cikal bakal dalam meneruskan keturunan bagi kedua orang tuanya dan sebagai penerus harta kekayaan yang ditinggalkan kedua orang tuanya kelak jika ia meninggal, namun pada kenyataanya tidak selalu demikian karena banyak fakta sorang anak dibuang oleh ibunya sendiri demi menutupi aib bagi dirinya sendiri dan keluarganya, kelahiran seorang anak meru- pakan anugerah dari sang pencipta. Perkembangan dewasa ini banyak terjadi kasus di masyarakat bahwa terjadi kelahiran anak akibat dari hubungan yang diluar perkawinan, hal tersebut membawa dampak akibat hukum bagamana akibat hukum si anak terhadap hubungan keluarga, waris, perwalian dan berkaitan dengan segala status dan kedudukan di mata hukum.

Perkawinan merupakan bagian dari suatu proses kehidupan manusia dengan masyarakat karena dalam perkawinan juga mempersatukan kedua belah pihak keluarga yang melangsungkan pernikahan. Di dalam masyarakat Indonesia sebagaimana kita tahu bahwa yang kawin sesungguhnya keluarga dengan keluarga, terlihat banyaknya aturan-aturan yang harus dijalankan (Wahyuni, 2008).

Suatu perkawinan yang pelaksanaanya sesuai dengan kaidah-kaidah agama akan terhidar dari kekuasaan ecogami dimana merupakan suatu perkawinan antara etnis, klan, suku dalam lingkungan yang berbeda, sedangkan dalam kekuasaan endogami ini sendiri merupakan suatu perkawinan atau etnis, klan, suku dalam lingkungan yang sama dan sebagainya. Menurut Sudarsono (1991), tujuan perkawinan itu adalah Membentuk keluarga yang bahagia dan kekal untuk itu suami dan istri perlu saling membantu dan melengkapi agar masing-masing dapat mengembangkan kepribadiannya, membantu dan mencapai kesejahteraan spiritual dan material.

Undang-Undang sendiri telah menjamin hak seorang anak sejak ia masi berada dalam kandungan ibunya, terkecuali anak yang sudah lahir dalam keadaan meninggal maka hak-hak itu sudah tidak dapat diberikan.

Sebelum berlakunya Undang-Undang Republik Indonesia Nomor 1 tahun 1974 tentang perkawinan (Undang-Undang Perkawinan), maka kedudukan anak diluar pernikahan juga tidak mempunyai pertalian keperdataan oleh ibunya apabila ibu dari anak tersebut tidak mengakuinya. Dengan 
Undang-Undang Republik Indonesia Nomor 1 tahun 1974 tentang Perkawinan tersebut maka anak luar kawin otomatis mempunyai hubungan perdata dengan ibu dan keluarga ibunya. Sejak berlakunya Undang-Undang Republik Indonesia Nomor 1 tahun 1974 tentang Perkawinan, seorang anak luar kawin tidak mempunyai hubungan perdata dengan ayah biologisnya jika sang ayah biologis tidak mengakuinya (Witanto, 2012).

Berdasarkan hal yang diuraikan mengenai perlindungan hukum terhadap anak luar kawin, masyarakat mulai melakukan upaya-upaya agar anak luar kawin mendapatkan kejelasan dan perlindungan hukum. Upaya tersebut salah satunya dilakukan oleh artis Machicha yang mengajukan permohonan meninjau kembali peraturan oleh Mahkamah Konstitusiterhadap Pasal 2 Ayat (2) dan Pasal 43 Ayat (1) Undang-Undang Republik Indonesia Nomor 1 tahun 1974 tentang Perkawinan, khususnya kepada Mahkamah Konstitusi.

Peristiwa hukum artis Machicha melangsungkan perkawinan dengan Moerdjiono yang hanya dilakukan secara agama atau biasanya disebut Nikah Sirri tanpa adanya pencatatan di Kantor Urusan Agama (KUA). Sedangakan sesuai penjelasan Pasal 2 Ayat (2) Undang-Undang Republik Indonesia Nomor 1 tahun 1974 tentang Perkawinan,suatu pernikahan sah adalah suatu perkawinan yang dicatatkan secara resmi kepada Kantor Urusan Agama. Apabila suatu perkawinan tidak dicatatkan ialah perkawinan yang tidak sah dan anak yang dihasilkan atas perkawinan ini tidak mempunyai kedudukan hukum sehingga anak tersebut dapat di kategorikan anak tidak sah atau anak yang lahir diluar perkawinan.

Akibat yang timbul dari itu sesuai Pasal 43 Ayat (1) Undang-Undang Republik Indonesia Nomor 1 tahun 1974 tentang Perkawinan, bahwa anak diluar perkawinan hanya mempunyai hubungan perdata dengan ibunya atau keluarga ibunya. Hak-hak seorang anak dalam hal ini ialah hak waris mewarisi antara pewaris yaitu si ayah dan si ahli waris ialah anak. Karena bagaimanapun si ayah tersebut tetap behubungan darah dengan si anak dan tetap menjadi ayah biologis si anak. Apakah anak tersebut mendapatkan haknya sebagai anak dari ayah biologisnya atau tidak berhak sama sekali seperti yang sudah tertulis dalam perundangundangan.

Melihat putusan yang dikeluarkan Mahkamah Konstitusi Republik Indonesia Nomor 46/PUUVIII/2010 hanya menjelaskankedududukan anak diluar perkawinan juga mendapatkan pertalian keperdataan dengan ayah, apabila dapat dibuktikan dengan ilmu pengetahuan dan teknologi. Putusan Mahkamah Konstitusi Republik Indonesia Nomor 46/PUU-VIII/2010 tidak menjelaskan mengenai bagian-bagian atau aturan-aturan tentang pembagian warisan antara anak luar kawin dan ayah biologisnya(Witanto, 2012).

Hukum waris yang berlaku di Indonesia belum terdapat hukum waris yang mengatur hukum waris secara universal atau berlaku nasional, hukum waris yang berlaku di Indonesia masih terbagi berdasarkan hukum waris Adat, hukum waris Islam, dan hukum waris Perdata (Kitab Undang-Undang Hukum Perdata). Pengaturan hukum adat yang berlaku di Indonesia tersebut memiliki pengaturan yang berbeda-beda terkait hukum waris. Hukum Adat merupakan cerminan dari keinginan masyarakat, karena hukum adaalah hukum yang tumbuh berkembang sejalan dengan perkembangan masyarakat. Dengan demikian, jika berbicara mengenai masalah hukum Adat maka segala yang berkaitan dengan hukum Adat tidak dapat dipisahkan dari masyarakat yang merupakan wadah dari hukum Adat itu sendiri. Sistem hukum dalam suatu masyarakat akan berkaitan dengan sistem dari masyarakat itu sendiri. Demikian pula dengan hukum adat karena hukum adat bertujuan untuk mempertahankan sistem masyarakat.

Hukum Adat dan perubahan sosial adalah dua hal dimana hubungan satu samalain bersifat 
berlawanan. Hukum selalu tunduk pada karakter normatifnya, sementaraperubahan sosial berjalan sesuai dengan kelangsungan empirisnya. Dengan sifat tersebut hukummenghendaki kemantapan dalam arus perubahan, dan dinamika sosial membutuhkanpenyesuaian pada hukum, agar hukum dapat fungsional, yang menjadi pemikiranadalah apakah hukum harus menyesuaikan dengan perubahan ataukah didalamperubahan kita harus mempertahankan hukum dalam kalangan masyarakat di Indonesia(Wahyuni, 2008).

Masyarakat Indonesia terdiri dari beragam suku dan bangsa, sehingga memiliki beragam adat istiadat dan hukum adat antara yang satu dengan yang lainnya, berbeda dan memiliki karakteristik tersendiri yang menjadikan hukum adat termasuk di dalamnya hukum waris menjadi pluralistis pula (Wahyuni, 2008). Terjadi peristiwa hukum yang menarik perhatian terjadi di kehidupan masyarakat Toraja dimana banyak kasus wanita melahirkan anak tanpa memiliki hubungan perkawinan dengan seorang pria sehingga nantinya akan menjadi masalah penting berkaitan kedudukan hukum dari anak yang dilahirkan dari pernikahan tersebut.

Menurut adat Toraja seorang anak yang dilahirkan diluar pernikahan hanya memiliki pertalian terhadap ibu dan keluaga ibunya. Hal tersebut dapat diartikan bahwa anak diluar kawin tersebut tetap mempunyai diakui dalam keluarga ibu terlepas dari dari pernikahan sah atau tidak dalam kehidupan masyarakat Toraja. Sehingga adanya Putusan Mahkamah Konstitusi Republik Indonesia Nomor 46/PUU-VIII/2010, penulis ingin mengidentifikasi bahwa anak yang lahir diluar perkawinan sah mendapatkan hak dan perlindungan dalam pembagian waris menurut Hukum Waris Adat Toraja.

\section{Metode Penelitian}

Penelitian ini menggunakan jenis penelitian yuridis normatif. Yuridis Normatif dalam pene- litian ini menggunakan beberapa pendekatan antara lain menggunakan pendekatan perundangundangan (Statute Approach), dan pendekatan kasus (Case Approach). Bahan hukum primer yang dimaksud adalah Kitab Undang-Undang Hukum Perdata, Undang-Undang Republik Indonesia Nomor 1 tahun 1974 tentang Perkawinan, UndangUndang Republik Indonesia Nomor 3 Tahun 1997 tentang Pengadilan Anak, Undang-Undang Republik Indonesia Nomor 23 Tahun 2002 Tentang Perlindungan Anak serta Putusan Mahkamah Konstitusi Republik Indonesia Nomor 46/PUUVIII/2010.

Sumber Bahan Hukum Sekunder:Buku-buku ilmu hukum; Jurnal ilmu hukum;Internet dan bahan yang terkait dengan permasalahan yang dibahas. Sumber Bahan Hukum Tresier, Selain dari bahan primer dan sekunder, peneliti juga menggunakan bahan hukum berupa bahan hukum tersier yang berupa bagian dari bahan non-hukum, tetapi jika itu dianggap perlu. Bahan-bahan non-hukum tersebut dapat berupa rujukan dari internet dan lainlainya selama bahan nonhukum tersebut masih sesuai dengan objek kajian permasalahan yang akan diteliti.Teknik Pengumpulan Bahan Hukum,studi kepustakaan.

Pengolahan data dalam penelitian ini menggunaka suatu metode diskriftif analisis dimana metode ini memberikan gambaran mengenai hubungan hukum, akibathukum dan perlindungan hukum bagi anak yang lahir di luarikatan perkawinan dan menganalisis mengenai pembagian warisan menurut Waris Adat di Toraja pasca adanya Putusan Mahkamah Konstitusi Republik Indonesia Nomor 46/PUU-VIII/2010.

\section{Perlindungan Hukum yang Diperoleh Anak Luar Kawin Jika Tidak Diakui oleh Ayah Biologisnya}

Anak di luar kawin menurut hukum merupaka anak tidak sah sehingga tidak dapat mendapatkan haknya berupa waris. Hukum memberi- 
kan pengecualianterhadap hal tersebut dengan hibah atau sedekah. Hal tersebut tidak lepas dari kedudukan anak luar kawin hanya memiliki keperdataan dengan ibu dan keluarga ibunya. Hakikatnya anak diluar perkawinan juga memiliki hak atas nafkah alimentasi atau hak nafkah bagi anak luar kawin termaksud yang lahir dari suatu hubungan zina dan anak sumbang. Perkembangan hukum terkait dengan anak luar kawin, termaksud anak zina dan anak sumbang, diberikan oleh Mahkamah Konstitusi Republik Indonesiamelalui putusan Nomor 46/PUU-VIII/2010, putusan tersebut menyatakan dua hal yaitu:

a) Pasal 43 Ayat (1) Undang-Undang Republik IndonesiaNomor 1 Tahun 1974 tentang perkawinan yang menyatakan:

"Anak yang dilahirkan di luar perkawinan hanya mempunyi hubungan perdata dengan ibunya dan keluarga ibunya"

Bertentangan dengan Undang-Uandang Republik Indonesia Tahun 1945 sepanjang dimaknai menghilangkan hubungan perdata dengan laki-laki yang dapat dibuktikan berdasarkan ilmu pengetahuan dan teknologi dan/atau alat bukti lain menurut hukum ternyata mempunyai hubugan darah sebagai ayahnya.

b) Pasal 43 Ayat (1) Undang-Undang Republik IndonesiaNomor 1 Tahun 1974 tentang perkawinan tidak memiliki kekuatan hukum yang mengikat, sehingga ayat tersebut harus dibaca

"Anak yang dilahirkan diluar perkawinan hanya mempunyai hubungan perdata dengan ibunya dan keluarga ibunya serta dengan laki-laki sebagai ayahnya yang dapat dibuktikan berdasarkan ilmu pengetahuan dan teknologi dan/atau alat bukti lain yang menurut hukum mempunyai hubungan darah, termaksud hubungan perdata dengan keluarga ayahnya" (Hartanto, 2015).

Berdasarkan pernyataan diatas bahwa seharusnya anak luar kawin juga memiliki hubungan keperdataan dengan ayah biologis anak luar kawin tersebut tidak hanya dengan ibu dan keluarga ibunya saja. Namun pengakuan normative dalam Putusan Mahkamah Konstitusi tersebut disyaratkan dengan pembuktian berdasarkan ilmu pengetahuan dan teknologi dan/ atau alat bukti sah menurut hukum.

Mahkamah Konstitusi Republik Indonesia dianggap sebagai reformasi hukum yang berhubungan dengan pengakuan pertalian keperdataan anak diluar perkawinan hanya memiliki pertalian dengan bapak dan ibu biologisnya, namun tidak diputuskan secara bulat. Tidak diakuinya seorang anak oleh ayah biologisnya adalah salah satu resiko perkawinan tidak sah menurut hukum karena tidak dicatatkan, sehingga memberikan resiko bagi lakilaki atau perempuan dan tidak merupakan resiko dari anak hasil hubungan mereka. Namun dengan adanya putusan mahkamah konstitusi ini bukan berarti melegalkan perzinaan karena salama ini anak luar kawin merasa memiliki nasib yang tidak adil dan tidak diakui secara legal, oleh karena itu putusan Mahkamah Konstitusi menegaskan adanya hubungan perdata antara anak yang dilahirkan dengan ayah dan ibunya. Dengan adanya putusan Mahkamah Konstitusi tersebut makan anak luar kawin diakui sejak anak itu lahir dan mempunyai hubungan waris dengan ayah biologisnya serta hak terhadap warisan ayah biologisnya juga semakin kuat (Hartanto, 2015).

\section{1) Hak Anak lahir dari perkawinan tidak sahdalam Menuntut HakPemeliharaan (Alimentasi) dari Orang Tua Lelaki biologisnya}

Hubungan antara seorang anak luar kawin dan Orang tua lelaki/ ayah biologisnya bukan hanya timbul dengan hubungan keperdataan saja namun juga secara berbanding terbalik sehingga menimbulkan hak bagi si ayah untuk mendapatkan pemeliharaan dari si anak luar kawin jika si anak telah dewasa. Hal ini merupakan bagian dari timbal balik yang bersifat mutlak, bahwa seorang anak mempunyai hak dalam mendapatkan pemeliharaan dan pendidikan dari orang tuanya sampai dengan 
si anak menginjak masa dewasa dan si anak juga berkewajiaban untuk mengurus dan memelihara ayah biologisnya pada saat telah menjelang tua, sebagaimana orang tua yang sah. Apabila seorang ayah biologis anak luar nikah telah mendapatkan putusan pengadilan untuk memberikan nafkah maupun memelihara anak kandungnya maka hukumnya wajib bagi ayah biologis tersebut untuk melaksanakannya. Namun hal tersebut jarang dalam praktek terlaksana ayah biologis memberikan nafkah kepada anak luar kawinya karena banyak dipengaruhi karena ayah biologisnya sudah berkeluarga dan memiliki anak-anak dari perkawinan yang sah, sehingga kewajibankewajiban terhadap anak luar kawin sering terabaikan.

Berkaitan dengan seorang anak yang lahir di luar kawin, maka perwalian akan di pegang oleh ibu hal ini sebagai akibat dari Pasal 43 Ayat (1) Undang-Undang Nomor 1 Tahun 1974 tentang Perkawinan yang menyebutkan seorang anak lahir dari pernikahan sah maka hanyamemiliki perikatan dengan ibu dan keluarganya. Sejak lahirnya Putusan Mahkamah KonstitusiRepublik Indonesia No. 46/PUU-VIII/2010, yang memutuskan memberikan pengakuan ketika anak laihir dari pernikahan tidak sah seorang ayah biologis yang terbukti sebagai ayah kandungnya wajib untuk memeberikan hak kepada anak tersebut untuk bertanggungjawab memberikan pemeliharaan (alimentasi) anatara anak luar kawin dengan ayah biologisnya menjadi terjalian. Seorang anak dan ibunya berpeluang untuk membuktikan seorang laki-laki yang mereka tunjuk adalah ayah yang memiliki hubungan darah dengan anak luar kawin tersebut, jika berdasarkan putusan pengadilan terhadap lelaki tersebut adalah ayah biologis dari anak yang lahir dari luar pernikahan sahnya maka secara hukum laki-laki tersebut memiliki tugas untuk memberikan nafkah, memeliharanya dan memberikan pendidikan kepada anak tersebut.

Berdasarkan putusan Mahkamah Konstitusi tersebut dapat dijadikan dasar adanya ruang peng- akuan terhadap anak hasil pernikahan tidak sah untuk mendapatkan haknya, namun dalam pandangan kehidupan masyarakat beban moral stigma negative masyarakat akan melekat pada anak tersebut akibat dari perbuatan orang tuanya. Putusan Mahkamah Konstitusi Republik IndonesiaNomor 46/PUU-VIII/ 2010 tersebut juga dapat menjadi dasar hukum untuk mengajukan permohonan penetapan pengesahan asal-usul anak luar kawin tersebut sebab substansinya Putusan Mahkamah Konstitusi bersifat umum.

\section{2) Perlindungan Hukum Anak Luar Kawin yang Diperoleh Jika Tidak Diakui oleh Ayah Bilogisnya Terkait Putusan Mahkamah Konstitusi}

Perlindungan anak yang diataur dalam Undang-Undang Republik IndonesiaNomor 1 Tahun 1974 tentang Perkawinan merupakan bentuk dari pelemahan terhadap perlindungan anak luar kawin, karena ketika orang tuanya tidak melakukan pernikahan yang sah dalam hal ini dicatat negara maka pernikahanya menjadi tidak sah. Syarat pencatatan pernikahan ini bersifat mutlak harus dipenuhi setiap warga negara Republik Indonesia hendak melangsungkan pernikahan. Pengakuan anak hasil pernikahan tidak sah dapat dilakukan dengan pengakuan suka rela, dimana seorang laki-laki yang mengakui anak luar kawin sebagai anak biologisnya.

Pengakuan anak akan menimbulkan sengketa baru karena pengakuan tersebut harus mendapatkan putusan pengadilan dengan pembuktian jika anak tersebut merupakan anak kandung dari lelaki itu. Pengakuan terhadap anak melalui pengadilan tersebut tidak diartikan sebagai mengesahkan pernikahan lelaki tersebut dengan wanita yang mengadung anak itu, namun mutlak mencari kebenaran hubungan antara lelaki dan anak tersebut adalah orang tua dan anak kandung, maka dengan adanya pengakuan tersebut hak anak wajib diberikan kepadanya oleh lelaki ayah kandungnya. Putusan Mahkamah Konstitusi Republik Indone- 
sia dapat menjadi dasar hukum bagi para ibu dan atau anak luar kawin jika ingin mengajukan permohonan penetapan pengesahan asal usul anak, hukum harus memberi perlindungan dan kepastian hukum yang adil terhadap status seorang anak yang dilahirkan dan hak-hak yang ada padanya, termasuk terhadap anak yang dilahirkan meskipun keabsahan perkawinannya masih dipertanyakan (Hartanto, 2015).

Menurut Liman (2013), apabila seorang lelaki hendak mengakui anak luar kawin yang menurut bukti medis adalah anak kandungnya maka harus memenuhi persyaratan sebagai berikut:

a) Sudah dewasa atau apabila masih dibawah umur maka setidak-tidaknya harus sudah berumur 19 tahun. Ditentukannya usia 19 tahun, dengan asumsi bahwa pada umur tersebut seorang lelaki dianggap sudah mampu mengetahui akibat dari perbuatannya. Akan tetapi jika lelaki tersebut belum mencapai usia 19 tahun maka pengakuannya harus ditunda sampai ia berusia 19 tahun atau sampai ia kawin, meskipun belum berusia 19 tahun.

b) Ada persetujuan dari ibu anak tersebut, jika anak yang akan diakui masih memiliki ibu atau ibunya masih hidup. Hal ini disyaratkan oleh undang-undang dengan maksud untuk melindungi ibu dari anak yang akan diakui. Apabila persyaratan ini tidak ada maka dengan sangat mudahnya seorang lelaki mengakui anak orang lain dengan tujuan untuk merugikan ibu dari anak tersebut, misalnya menghalanghalangi perkawinan antara kedua orang tua biologis anak itu.

Suatu pengakuan secara sukarela atas anak luar kawin dapat batal apabila pengakuan tersebut dilakukan(Liman, 2013), krena akibat paksaan atau salah paham atau tertipu;Seorang anak yang masih dibawah umur akibat suatu bujukan;Seorang anak yang masih berumur 18 tahun dan belum kawin kecuali diakui pada saat dilangsungkannya perkawinannya; Tanpa persetujuan dari ibu anak yang akan diakui sedangkan ibu tersebut masih hidup; dan Seorang lelaki yang berada dibawah pengampuan.

Preoses pengakuan anak di luar nika dapat dilakukan dengan ayah dari anak luar kawin mengakui secara suka rela dan menghadap kepada notaris untuk melakukan permohonan kepada notaris untuk membuatkan akta autentik yang dibuat pejabat pencatatan sipil dan dibukukan sesuai dengan hari dan tanggal kelahiran anak tersebut. Namun untuk dilakukan atas kepentingan anak maka pengakuan tersebut dapat diberlakukan surut.

Pengecualian terhadap pengakuan surut ini tidak dapat digunakan dalam kasus "Anak luar kawin yang tidak diakui sah oleh ayah biologisnya adalah anak yang lahir diluar perkawinan orang tua biologisnya dan tidak diakui sebagai anak oleh bapak atau ayah biologisnya. Anak luar kawin ini tidak mempunyai hubungan perdata dengan ayah biologisnya. Namun sebelum berlakunya UndangUndang Republik IndonesiaNomor 1 Tahun 1974 tentang Perkawinan maka anak luar kawin juga tidak mempunyai hubungan perdata dengan ibu yang melahirkannya jika sang ibu tidak mengakuinya. Akan tetapi dengan berlakunya UndangUndang Republik IndonesiaNomor 1 Tahun 1974 tentang Perkawinan tersebut maka anak luar kawin otomatis mempunyai hubungan perdata dengan ibudan keluarga ibunya."

Putusan Mahkamah Konstitusi Republik Indonesia berkaitan pengujian Pasal 43 UndangUndang Perkawinan terhadap pengakuan anak luar kawin merupakan suatu bentuk pengakuan terhadap anak luar kawin untuk mendapatkan kedudukan sejajar sama halnya anak sah. Pengakuan anak luar kawin tersebut merupakan suatu upaya memberikan perlindungan hukum kepada anak luar kawin saat ini. Namun putusan itu mendapatkan pengecualian terhadap anak luar kawin yang lahir karena ibunya seorang yang berprofesi sebagai pekerja seks komersial, yang tidak mungkin memerlukan pembuktian ayah kandung sebenarnya anak luar kawin tersebut. 
Putusan mahkamah Konstitusi ini satu tujuan dengan Konvensi Hak Anak yang mengatur bahwa anak akan didaftar segera setelah lahir dan akan punya hak sejak lahir, hak untuk memperoleh suatu kebangsaan, dan sejauh mungkin, hak untuk mengetahui dan diasuh oleh orang tuanya. Selanjutnya Pasal 7 ayat (1) Undang-Undang Nomor 23 Tahun 2002 tentang Perlindungan Anak menyebutkan secara tegas:" Setiap anak berhak untuk mengetahui orang tuanya, dibesarkan, dan diasuh oleh orang tuanyasendiri."

Jika ayah biologisnya tidak mengakui anak luar kawin sebagai anak biologisnya, maka ibu bisa menjadi perwalian dalam pembuktian ayah biologinya adalah ayahnya yang mempunyai ikatan darah, maka dari itu dengan adanya. Putusan Mahkamah Konstitusi Republik IndonesiaNomor 46/PUU-VIII/2010 anak luar kawin yang terlahir tampa adanya ikatan pernikahan antara kedua orang tuanya status hukumnya dapat dibuktikan berdasarkan ilmu pengetahuan dan teknologi (misal hasil test deoxyribonucleid/DNA) sehingga perlindungan yang didapatkan oleh anak luar kawin adalah pemohon ibu dari anak luar kawin dapat membawa alat bukti yang dapat menguatkan bahwa anak tersebut adalah anak biologis dari ayahnya, seiring dengan kemajuan ilmu pengetahuan dan teknologi yang berkembang pesat sehingga memperkenalkan alat-alat bukti baru yang lebih canggih.

Anak luar kawin dapat mengajukan tuntutan pengakuan terhadap dirinya kepada ayah biologisnya apabila ayah biologisnya tidak mengakui keberadaannya. Pengujian keabsahan anak tersebut dilakukan dengan metode kesehatan dan tekhnologi yang dipercaya masyarakat dan norma hukum sebagai pembuktian yang akurat dan terpercaya untuk memberikan kebenaran status anak tersebut. Sehingga setelah hasil tes tersebut terbukti maka akan memberikan kepastian hukum kepada anak untuk mendapatkan pertalian dengan ayah kandungnya.

Jika ayah biologis anak tersebut setelah mendapat putusan pengadilan terbukti sebagai ayah biologis anak diluar nikahnya namun tidak secara sukarela melakukan putusan pengadilan dengan tetap tidak mengakui dan tidak memberikan pemeliharaan kepada anak luar nikahnya maka si ibu dapat mengajukan permohonan pelaksanaan putusan (eksekusi) berdasarkan bab eksekusi dalam hukum acara perdata, jika ayah biologis adalah pegawai negeri atau pegawai dari sebuah perusahaan, maka pelaksanaan putusan dapat dilakukan langsung kepada bendahara pembayar gaji agar gaji milik ayah biologis yang tidak mengakui anak luar nikahnya secara langsung disisikan untuk pelaksanaan putusan.

\section{Akibat Hukum yang Timbul Terhadap Anak Luar Kawin dalam Pembagian Waris Adat Toraja}

MenurutHukum Adat di Toraja, apabila terdapat anak diluar pernikahan sah akan memberikan aib bagi ibu dan keluarga ibunya, namun hal ini dapat merugikan anak yang akan lahir karena akan di beri cap sebagai anak haram. Stigma tersebut sampai kapanpun tidak bisa diubah, sehingga merugikan anak yang akan lahir, walaupun anak luar kawin ini merupakan hasil hubungan terlarang yang dilakukan oleh orangtuanya, sehingga anak luar kawin ini harus menanggung akibat baik secara hukum dan secara sosial yang dilakukan kedua orang tuanya, karena anak luar kawin.

Hukum Adat di Toraja bersifat parental atau bilateral yaitu menarik garis keturunan kedua belah pihak dari ayah dan dari ibu, dimana kewajiban untuk membiayai kehidupan dan pendidikan seorang anak, tidak hanya dibebankan kepada pihak ibu saja, namun juga kepada pihak ayah juga. Apabila salah satu dari orang tuanya tidak menepati kewajibannya,hal itu dapat dituntut mengenai biaya selama anak tersebut masih belumdewasa (Wahyuni, 2008). Di kalangan masyarakat adat Toraja, jika orang tua yang tidakmempunyai anak sah tetapi mempunyai anak luar kawin, maka anak luarkawin yang berkelakuan baik terhadap ke- 
luarga ayah biologisnya akanmendapat warisan dari keluarga ayah biologisnya. Jika ayahbiologisnya mempunyai anak sah dan anak luar kawin, maka dalampewarisan anak sah akan mendapat lebih banyak dari anak luar kawin,dikarenakan anak luar kawin itu dapat mewaris dari ayah biologisnyatidak sebanyak anak sah yang sah (Wahyuni, 2008).

Dilingkungan masyarakat Adat Toraja anak luar kawin selalu menjadi cemooh, tapi sangat ironis ketika ayah biologisnya tidak ingin bertanggung jawab atas perbuatanya tersebut dan juga jarang terkena dampak sosialnya, disamping menurut hukum lelaki itu tidak diberikan kewajiban untuk memberikan nafkah dan peliharaan terhadap anak luar nikah tersebut. Sehingga anaklura nikah hanya memiliki ikatan keperdataan dengan ibu dan keluarganya, demikian seperti bunyi pasal Pasal 43 Ayat (1) Undang-Undang Republik Indonesia Nomor 1 Tahun 1974 tentang Perkawinan menentukan bahwa ia hanya mempunyai hubungan perdata dengan ibunya dan keluarga ibunya, namun semejak adanya Putusan Mahkamah Konstitusi Republik Indonesia Nomor 46/PUU-VIII/ 2010 maka hubungan perdata tidak hanya pada pihak ibu dan keluarga ibu saja namun berhubungan perdata dengan pihak ayah biologisnya dan keluarga ayahnya tersebut.

Anak yang lahir dari pernikahan tidak sah atau anak luar kawin berhak mendapatkan hak untuk hidup dan dapat menikmati kehidupan selayaknya anak-anak, namun berbeda dengan masyarakat Adat Toraja, yang menempatakan pertalian keperdataan anak tidak sah dengan ibu dan keluarganya, namun jika ayah biologisnya tidak mengakui anak luar kawin sebagai darah dagingnya, maka anak tersebut tidak memiliki ikatan keperdataan dengan ayah biologisnya. Semejak berlakunya Putusan Mahkamah konstitusi nomor 46/PUU-VIII/2010, dimana putusan ini berlaku bagi semua anak luar kawin di Indonesia, sehingga anak luar kawin di masyarakat Adat Toraja ini berhak atas penghidupan yang layak dan warisan dari ayah biologisnya.

Hukum Adat Toraja sendiri menurut Hakim (2016) mempunyai beberapa lembaga yang diyakini oleh masyarakat toraja itu sendiri yang dinamakan Kombongan. Kombongan sebagai pilar demokrasi dan sebagai wadah yang mengawal dinamika adat sesuai perubahan kebutuhan masyarakatnya. Sejak To Banua Puan, maka salah satu ciri yang mendasar dalam komunitas adalah musyawarah yang dinamakan Kombongan.Kombongan tersebut sudah melembaga dari generasi ke generasi. Semboyan Kombongan yaitu "Untesse batu mapipang" artinya dapat memecahkan batu cadas yang mempunyai makna bahwa apapun dan bagaimanapun asal disetujui melalui Kombongan dapat merubah, menghapus atau membuat aturan adat yang baru.

\section{Simpulan}

Kedudukan anak luar kawin menurut Putusan Mahkamah Konstitusi Republik Indonesia Nomor 46/PUU-VIII/ 2010 diakui dalam arti anak luar kawin mempunyai hubungan perdata dengan ibunya dan keluarga ibunya dan keluarga ayahnya serta dengan laki-laki sebagai ayahnya. Namun demikian harus dapat dibuktikan bahwa anak luar kawin tersebut berdasarkan bukti ilmu pengetahuan dan teknologi dan atau alat bukti lain yang menurut hukum mempunyai hubungan darah dengan ayahnya. Putusan Mahkamah Konstitusi Republik Indonesiatersebut tidak secara khusus menjelaskan jenis anak luar kawin yang dapat mempunyai hubungan perdata dengan ayahnya, sehingga dapat saja ditafsirkan secara luas bahwa semua jenis anak luar kawin (termaksud anak zina dan anak sumbang) dapat mempunyai hubungan perdata dengan ayahnya.

Adanya anak luar kawin pada kehidupan masyarakat Adat Toraja, perlu dipertegas kedudukan dan hak anak luar kawin terhadap harta warisandari ayah biologisnya. Anak luar kawin 
tetap berhak mewaris dari harta ibunyadan kedudukannya seperti pewaris lainnya, serta tidak ada persoalan mendapat bagian warisan dari keluarga ibunyamaupun dari ayah biologisnya apabila ia diakui olehayahnya tersebut sebagai anak kandungnya. Namun jika tidak di akui maka ibu dari anak luar kawin tersebut dapat menuntut hak-hak anak tersebut, karena dengan adanya putusan Mahkamah Konstitusi Republik IndonesiaNomor 46/PUU-VIII/ 2010 yang berlaku bagi semua anak luar kawin, juga mempunyai hubungan perdata dengan ayah biologisnya, sehingga anak tersebut memiliki hak pemeliharaan dan warisan dari ayah biologisnya. Sehingga cara penyelesaian untuk melindungi hak-hak anak luar kawin tersebut dengan menggunakan cara penyelesaian menurut Hukum Waris Adat Toraja.

\section{Saran}

Hukum Waris Adat Toraja, yaitu musyawarah mufakat antara kedua keluarga belah pihak dan Lembaga, diharapkan mampu menjadi sumbangan bagi permasalahan hukum ini. Penggunaan Hukum Waris Adat digunakan untuk mengisi kekosongan hukum sehingga melahirkan keadilan, kepastian dan kemanfaatan bagi masyarakat dan negara.

\section{DAFTAR PUSTAKA}

Adiarta, I Wayan. 2015. Tinjauan Yuridis Tentang Kedudukan Anak Luar Kawin Dalam Pembagian Warisan. Jurnal Ilmu Hukum Legal Opinion. Volume 3. Nomor 4.

Hadikusuma, Hilman. 2007. Hukum Perkawinan Indonesia Menurut: Perundangan, Hukum Adat, Hukum Agama. Mandar Maju. Jakarta.

Hakim, Fadhiil Ali. 2016. Hukum Adat Tanah di Toraja. http:/ / segalahukum.blogspot.co.id/2016/04/ hukum-adat-tanah-di-toraja.html. Diakses pada tanggal 20-4-2017.
Hartanto, J. Andy. 2015. Hukum Waris Kedudukan dan Hak Waris Anak Luar Kawin Menurut "Burgelijk Wetboek" Pasca Putusan Mahkamah Konstitusi. LaksBang Juatitia. Surabaya.

Kitab Undang-Undang Hukum Perdata (KUHPer).

Putusan Mahkamah Konstitusi Republik Indonesia Nomor 46/PUU-VIII/2010. Jakarta.

Satrio, J. 1992. Hukum Waris. Alumni. Bandung.

Soekanto, Soerjono \& Soleman Taneko. 2002. Hukum Adat Indonesia. Cet.5. Raja Grafindo Persada. Jakarta.

Soepomo. 1996. Bab-Bab Tentang Hukum Adat. Pradya Paramita. Jakarta.

Subekti, R. 1977. Pokok-pokok Hukum Perdata. Intermasa. Jakarta.

Undang-Undang Dasar Republik Indonesia Tahun 1945. Jakarta.

Undang-Undang Republik Indonesia Nomor 1 Tahun 1974 tentang Perkawinan. Jakarta.

Undang-Undang Republik Indonesia Nomor 23 Tahun 2002 tentang Perlindungan Anak. Jakarta.

Undang-Undang Republik Indonesia Nomor 4 Tahun 1979 tentang Kesejateraan Anak. Jakarta.

Wahyuni, Sri. 2008. Kedudukan Anak Luar Kawin Menurut Hukum Waris Adat Di Kecamatan Boyolali Kabupaten Boyolali. Tesis. Magister Kenotariatan. Universitas Diponegoro. Semarang.

Witanto, D.Y. 2012. Hukum Keluarga Hak dan Kedudukan Anak Luar Kawin. Prestasi Pustaka. Jakarta.

\section{How to Cite:}

Tadu, Olivia Irianty Logo. 2017. Perlindungan Hukum Terhadap Anak Luar Kawin dalam Pembagian Waris Adat Toraja. Jurnal Cakrawala Hukum. 8 (1): 96-105. 